\title{
Which One is The Better Radiotherapy Technique for Patients with Thoracic Esophageal Tumors, IMRT or VMAT?
}

\author{
A. Emre KARAOGUZ ${ }^{1}$, Zümre A. ALICIKUS ${ }^{1}$, Dogukan AKCAY ${ }^{1}$, \\ Hülya ELLIDOKUZ ${ }^{2}$, Kadir AKGUNGOR ${ }^{3}$ \\ ${ }^{1}$ Dokuz Eylul University, Faculty of Medicine, Department of Radiation Oncology \\ ${ }^{2}$ Dokuz Eylül University, Oncology Institute, Department of Biostatistics and Medical Informatics \\ ${ }^{3}$ Dokuz Eylül University, Faculty of Arts and Science, Izmir, TURKEY
}

\begin{abstract}
Comparison of IMRT and VMAT techniques in thoracic esophageal tumors. IMRT and VMAT plans were created for a total of 10 thorax-located esophagus patients. All plans were compared in terms of $\mathrm{HI}$ and $\mathrm{Cl}$ for PTV; $\mathrm{V}_{5}, \mathrm{~V}_{10}, \mathrm{~V}_{20}$ and mean lung dose parameters for total lung; $V_{30}, V_{40}$ and mean heart dose for the heart; and the Dmax for the medulla spinalis. IMRT and VMAT techniques yielded similar results with respect to $\mathrm{HI}$ and $\mathrm{Cl}$ values ( $\mathrm{p}>0.05$ ). Median mean lung dose was found to be lower in VMAT (11.77 Gy) technique compared to IMRT (12.05 Gy). While the lowest lung median $\mathrm{V}_{5}(67.17 \%)$ and $\mathrm{V}_{10}(41.95 \%)$ values belonged to IMRT, the $V_{20}$ value was achieved with VMAT (17.85\%) planning. Median mean heart dose was found the lowest in VMAT (28.81 Gy) and the highest IMRT (29.31 Gy) planning. The lowest heart median V30 value was obtained with IMRT (43.00\%) and median $\mathrm{V}_{40}$ value was obtained with VMAT (18.95\%) planning. The median mean medulla spinalis maximum dose was found to be lower with VMAT (41.54 Gy), with no statistically significant difference between them $(p=0.074)$. VMAT technique was better for reducing cardiovascular and medulla spinalis doses with reduced duration of treatment time and dosimetric uncertainties, while YART technique provides higher PTV control with less low-dose lung volume. Both threatment options have advantages and disadvantages over normal tissue and tumor volume compared to each other, and should be evaluated according to the other clinical conditions of the patient.
\end{abstract}

Keywords: Dose-volume parameters, Esophageal cancer, IMRT, VMAT

\section{ÖZET}

\section{Torakal Yerleşimli Özefagus Tümörlerinde Hangi Radyoterapi Tekniği Daha İyi: YART ya da VMAT?}

Çalışmanın amacı, torakal özefagus tümörlerinde YART ve VMAT tekniklerinin karşılaştııımasıdır. Toplam 10 torakal yerleşimli özefagus hastası için YART ve VMAT planları oluşturuldu. Tüm planlar PTV için $\mathrm{HI}$ ve $\mathrm{Kl}$, toplam akciğer için $\mathrm{V}_{5}, \mathrm{~V}_{10}, \mathrm{~V}_{20}$ ve ortalama akciğer dozu parametreleri; kalp için $V_{30}, V_{40}$ ve ortalama kalp dozu; medulla spinalis için Dmax parametresi açısından karşılaştırılı. YART ve VMAT teknikleri HI ve KI değerleri bakımından benzer sonuçlar ortaya koymuştur ( $p>0.05$ ). Medyan ortalama akciğer dozu VMAT (11.77 Gy) planlamada YART (12.05 Gy) planlamaya kıyasla daha düşük bulunmuştur. En düşük akciğer medyan $\mathrm{V}_{5}(\% 67.17)$ ve $\mathrm{V}_{10}$ (\%41.95 Gy) değerleri YART planlamaya ait iken, $V_{20}$ değeri VMAT (\%17.85) planlamada elde edilmiştir. Medyan ortalama kalp dozu en düşük VMAT (28.81 Gy) ve en yüksek YART (29.31 Gy) planlarda bulunmuştur. En düşük kalp medyan $V_{30}$ değeri YART planlamada (\%43.00), en düşük medyan $V_{40}$ değeri ise VMAT (\%18.95) planlamada elde edilmiştir. Medyan ortalama medulla spinalis maksimum dozu VMAT (41.54 Gy) planlamada daha düşük bulunup, bu parametre bakımından iki teknik arasında istatistiksel açıdan anlamlı fark gözlenmemiştir ( $p=0.074$ ). YART tekniği akciğerlerde daha az düşük doz hacmi sağlarken, VMAT tekniği tedavi süresinin kısalması ve dozimetrik belirsizliklerin azalması ile kardiyovasküler ve medulla spinalis dozlarının düşüklügü bakımından daha üstündür. Her iki tekniğin normal doku ve tümör açısından avantaj ve dezavantajları vardır ve tercih hastanın diğer klinik özellikleri dikkate alınarak yapılmalıdır.

Anahtar Kelimeler: Doz-volüm parametreleri, Özefagus kanseri, YART, VMAT 


\section{INTRODUCTION}

According to 2014 cancer statistics, with nearly 18.000 new cases annually, esophageal cancer is the 10th most common type of cancer and the 5 -year survival rates are quite low. ${ }^{1}$ Esophageal carcinoma is usually caught in the advanced stage due to the absence of serosa, which serves as an anatomic barrier and rapidly invading surrounding tissue due to the rich lymphatic drainage network, making rapid lymphatic spread. ${ }^{2}$ The primary treatment approach is surgery and low survival and high recurrence rates in local advanced stage tumors have shown that surgical treatment alone is inadequate..$^{3-5}$ The addition of radiotherapy (RT) and/ or chemotherapy (CT) to surgical treatment has resulted in a significant improvement in both recurrence and survival outcomes. ${ }^{6-8}$ As a result, side effects due to treatment have become increasingly important due to the improvement in the survival of esophageal cancer patients treated with multimodal treatments. For this reason, the importance of the clinical effects of radiotherapy techniques and the doses received by critical normal tissues has increased in terms of reducing side effects that may affect the quality of life.

The main goal of radiotherapy is to achieve the maximum dose in the tumor, while the surrounding normal tissues are exposed to minimum doses. For this reason, in situations where target tumor volumes are surrounded with radiation-sensitive critical organs (lungs, heart, medulla spinalis, etc.) and especially in the case of midline located tumors, the radiotherapy technique is very important. At this point, the advanced radiotherapy techniques of Intensity Modulated Radiotherapy (IMRT) and Volumetric Modulated Arc Therapy (VMAT) are superior to 2-dimensional (2D) and 3-dimensional Conformal Radiotherapy (3D-CRT). ${ }^{9}$ For this reason, today, the IMRT technique using static angles and the VMAT technique providing volumetric treatment have begun to be used instead of 3DCRT in the treatment of midline located tumors such as the esophagus. The advantages and disadvantages of both of these advanced techniques differ from one another according to the location of the esophageal cancer. In a study comparing the IMRT and VMAT techniques in all esophageal tumor locations, it was observed that a better lung mean dose and $\mathrm{V}_{5}$ (lung volume receiving $5 \mathrm{~Gy}$ ) value was obtained in all locations with the IMRT technique compared to VMAT. However, it was found that the mean heart doses, maximum medulla spinalis dose $\left(\mathrm{D}_{\max }\right)$ and lung $\mathrm{V}_{20}$ values were increased in the IMRT plans in regions with medial and lower thoracic locations. ${ }^{9}$

The aim of our study is to compare the IMRT and VMAT techniques, which are radiotherapy techniques currently used in patients with thorax-located esophageal cancer. The comparison of treatment plans made in a dosimetric manner with respect to the tumor target and normal tissues that are important in terms of side effects.

\section{PATIENTS and METHODS}

Ten consecutive patients with thoracic esophageal tumor who underwent for neoadjuvant chemoradiotherapy between January 2013 and December 2015 were included in this study. Lung, heart, and medulla spinalis dose data obtained in different plans were analyzed and the results were compared.

This study was approved by the Ethics Committee of Dokuz Eylul University Medical School (2016/04-01).

The total radiotherapy dose is $4500 \mathrm{cGy}$ (at a dose of $180 \mathrm{cGy} / \mathrm{fr}, 5$ days a week, a total of 5 weeks). The patients were administered 5-FU/cisplatinbased concurrent chemotherapy. Using the CT simulation data of patients, treatment target volumes and all critical organs (lungs, heart, medulla spinalis) were redefined by a senior radiation oncologist in order to minimize interobserver differences. The IMRT and VMAT plans re-planned for 10 patients. The recommendations in the ICRU (The International Commission on Radiation Units and Measurements) Report No.83 were taken into consideration in all the planning. ${ }^{10}$

\section{CT Simulation}

In the study, images previously obtained from the "Siemens" brand, "Emotion" model computerized tomography-simulator device were used. 
On the day of CT simulation, the patients drink $500 \mathrm{cc}$ of water and $10 \mathrm{cc}$ of contrast agent after at least 2 hours of fasting before imaging. CT images were taken using a wing board T-bar with supine position and arms held above, with a 3-mm section interval, from the 2 nd cervical vertebra to the 2 nd lumbar vertebra. The subsequently obtained CT simulation images were transferred to the "Eclipse v11" treatment planning system.

\section{Target Tumor Volume and Normal Tissue Con- touring}

Gross tumor volume (GTV) was determined using positron emission computed tomography (PETCT) images of the mid-thoracic esophageal tumor. The clinical target volume (CTV) was contoured so as to be $5 \mathrm{~cm}$ superior and inferior to the GTV and $1 \mathrm{~cm}$ in the radial direction. The CTV contour includes the tumor adjacent esophagus and the paraoesophageal and subcarinal lymphatics, which are important in terms of subclinical disease. Planning tumor volume (PTV) was obtained by expanding CTV contour $5 \mathrm{~mm}, 10 \mathrm{~mm}$, and $7 \mathrm{~mm}$ from the posterior, anterior and lateral, respectively.

Bilateral lung volume was formed by contouring the entire lung tissue observed in the parenchyma window. The heart volume was formed by contouring to include the pericardium at the lowest level observed from the entrance of the main large vessels. The medulla spinalis was contoured as the spinal canal space.

\section{Intensity Modulated Radiotherapy (IMRT) Technique}

In the IMRT plans, five $15 \mathrm{MV}$ fields with nonoverlapping centerlines were used. The beam angles are chosen according to patient anatomy, so that each beam angle are patient specific.

Dose constraints for target and normal tissue were determined as minimum $\mathrm{D}_{95} \%=4275 \mathrm{cGy}(95 \%$ dose) and maximum $\mathrm{D}_{107} \%=4815$ cGy $(107 \%$ dose) for PTV, $\mathrm{V}_{30}<40 \%, \mathrm{~V}_{40}<30 \%$, and mean heart dose (MHD) $<3500 \mathrm{cGy}$ for the heart, $\mathrm{V}_{5}<$ $65 \%, \mathrm{~V}_{10}<45 \%, \mathrm{~V}_{20}<20 \%$ and mean lung dose (MLD) $<2000$ cGy for the lungs, and $\mathrm{D}_{\text {max }}=4500$ cGy for the medulla spinalis in the optimization, in accordance with ICRU Report 83 rules. The plans were optimized so that $95 \%$ of the PTV volume would receive $95 \%$ of the total dose and so as to keep normal tissue doses at the lowest possible level. The optimization of the plans was done using the "Eclipse v11" treatment planning system with the inverse planning technique.

\section{Volumetric Modulated Arc Therapy (VMAT) Technique}

In all cases, two full arcs of $15 \mathrm{MV} \mathrm{X}$-rays (CW$\mathrm{CCW}$ ) were applied, with the starting and ending angles 179-181 degrees. To increase the homogeneity on the target and obtain a clearer dosimetric result, each arc was limited to 180 control points. The collimator angles used in the plans varied between 10 and 30 degrees according to the PTV shape.

IMRT and VMAT plans were optimized using Analytical Anisotropic Algorithm (AAA). In our study, the planning techniques were also compared in terms of homogeneity index (HI) and conformity index (CI). The homogeneity index (HI) used by Wang et al. ${ }^{11}$ was calculated using the following formula:

$$
\mathrm{HI}=\mathrm{D}_{\% 5} / \mathrm{D}_{\% 95}
$$

$\mathrm{D}_{5}$ is the dose received by $5 \%$ of the PTV (maximum dose), and D95 is the dose received by of 95\% of the PTV (minimum dose). The homogeneity index value being close to 1 indicates that the plan is more homogenous.

The conformity index (CI) can be used as part of the optimization process. The conformity index is an indication of how much of the dose desired to be prescribed is within the target volume. In this study, the conformity index formula defined by Paddick et al. was used. ${ }^{12}$ The formula contains target volume covered by prescription isodose volume $\left(\mathrm{TV}_{\mathrm{PIV}}\right)$, target volume (TV) and prescription isodose volume (PIV).

$$
\mathrm{CI}=\left(\mathrm{TV}_{\mathrm{PIV}}\right)^{2} /(\mathrm{TV} \mathrm{x} \text { PIV })
$$

TVPIV represents the target volume contained in the defined isodose, and PIV represents the isodose volume defined. According to this definition, it is mentioned that an ideal conformity is obtained if the CI value is equal to 1 . 


\begin{tabular}{|c|c|c|c|c|}
\hline & \multicolumn{4}{|c|}{ PTV } \\
\hline & \multicolumn{2}{|c|}{$D_{95}$} & \multicolumn{2}{|c|}{$D_{98}$} \\
\hline & IMRT & VMAT & IMRT & VMAT \\
\hline Median & 45.19 & 43.99 & 44.68 & 43.28 \\
\hline (Min-Max) & $(43.32-46.04)$ & $(42.88-44.58)$ & (42.10-45.68) & $(41.90-44.07)$ \\
\hline Mean & 45.03 & 43.93 & 44.44 & 43.22 \\
\hline $\mathrm{SD}^{*}$ & 0.87 & 0.52 & 1.02 & 0.67 \\
\hline$p$ & \multicolumn{2}{|c|}{0.028} & \multicolumn{2}{|c|}{0.028} \\
\hline
\end{tabular}

\section{Statistical Analysis}

In the statistical analysis, the "Non-parametric" test was used because the number of cases in the study was less than 30. In related data comparisons, the "Wilcoxon Signed Rank" test was used to compare double related data. For statistical significance, $p<$ 0.05 was considered necessary.

\section{RESULTS}

\section{Planning Target Volume (PTV)}

The $\mathrm{D}_{95}$ and $\mathrm{D}_{98}$ values of PTV in the two different planning techniques are given in detail in Table 1. In all cases, the minimum mean $\mathrm{D}_{95}$ and $\mathrm{D}_{98}$ values for PTV belong to VMAT planning (43.93 Gy and $43.22 \mathrm{~Gy})$, while the maximum $\mathrm{D}_{95}$ and $\mathrm{D}_{98}$ values belong to IMRT planning (45.03 Gy and 44.44 Gy).
Table 2 shows the homogeneity and conformity index values of PTV. Although there was a statistical difference between the $\mathrm{D}_{95}$ and $\mathrm{D}_{98}(\mathrm{p}<0.05)$, there was no statistically significant difference between the $\mathrm{HI}$ and CI parameters ( $\mathrm{p}>0.05)$.

\section{Total Lung}

The median mean lung dose was lowest in VMAT (11.77 Gy) planning. The lowest median $\mathrm{V}_{5}(67.17$ Gy) and $\mathrm{V}_{10}(41.95 \mathrm{~Gy})$ values were obtained in IMRT planning and the lowest median $\mathrm{V}_{20}$ value was obtained in VMAT (17.85 Gy) planning. The total lung doses obtained in the IMRT and VMAT plans are given in detail in Table 3.

In terms of total lung parameters, a statistical difference was observed between IMRT and VMAT in terms of the $\mathrm{V}_{5}$ and $\mathrm{V}_{10}$ parameters $(\mathrm{p}=0.005$ and 0.038 ). While no statistical difference was observed in terms of the total lung $\mathrm{V}_{20}$ and MLD

\begin{tabular}{|c|c|c|c|c|}
\hline & \multicolumn{4}{|c|}{ PTV } \\
\hline & \multicolumn{2}{|c|}{$\mathrm{HI}$} & \multicolumn{2}{|c|}{ Cl } \\
\hline & IMRT & VMAT & IMRT & VMAT \\
\hline Median & 1.08 & 1.07 & 0.83 & 0.83 \\
\hline (Min-Max) & $(1.05-1.55)$ & $(1.06-1.44)$ & $(0.70-0.88)$ & $(0.58-0.88)$ \\
\hline Mean & 1.12 & 1.10 & 0.80 & 0.80 \\
\hline $\mathrm{SD}^{*}$ & 0.15 & 0.12 & 0.06 & 0.09 \\
\hline$p$ & \multicolumn{2}{|c|}{0.678} & \multicolumn{2}{|c|}{0.575} \\
\hline
\end{tabular}




\begin{tabular}{|c|c|c|c|c|c|c|c|c|}
\hline \multicolumn{9}{|c|}{ Total Lung } \\
\hline & \multicolumn{2}{|l|}{$\mathbf{V}_{5}$} & \multicolumn{2}{|l|}{$v_{10}$} & \multicolumn{2}{|l|}{$\mathbf{V}_{20}$} & \multicolumn{2}{|l|}{ MLD } \\
\hline & IMRT & VMAT & IMRT & VMAT & IMRT & VMAT & IMRT & VMAT \\
\hline Median & 67.17 & 69.40 & 41.95 & 44.13 & 21.34 & 17.85 & 12.05 & 11.77 \\
\hline (Min-Max) & (56.70-79.80) & $(63.40-90.00)$ & $(36.32-59.30)$ & (38.40-68.20) & $(19.57-33.20)$ & (12.50-35.90) & $(9.87-17.14)$ & $(10.01-17.59)$ \\
\hline Mean & 63.64 & 74.04 & 42.38 & 47.25 & 22.69 & 20.00 & 12.40 & 12.64 \\
\hline $\mathrm{SD}^{*}$ & 7.09 & 9.32 & 6.59 & 9.10 & 4.16 & 6.94 & 2.00 & 2.20 \\
\hline$p$ & 0.005 & & 0.038 & & 0.092 & & 0.575 & \\
\hline
\end{tabular}

parameters, values approximately $3.5 \%$ and $0.25 \%$ lower were obtained with VMAT compared to IMRT, respectively.

\section{Heart}

The median mean heart dose was found the lowest in VMAT (28.81 Gy) plans. The lowest median $\mathrm{V}_{30}$ value was found in IMRT planning (43.00 Gy) and the lowest median $\mathrm{V}_{40}$ value was found in VMAT (18.95 Gy) planning. No statistically significant difference was observed between the two techniques in terms of $\mathrm{V}_{30}$ and MHD ( $\mathrm{p}>0.05$ ), while a statistically significant difference was observed in terms of the $\mathrm{V}_{40}$ parameter $(\mathrm{p}=0.005)$. Although there were no significant differences in terms of the heart $\mathrm{V}_{30}$ and MHD parameters, the VMAT technique yielded values approximately $8 \%$ and $1.5 \mathrm{~Gy}$ lower than the IMRT technique, respectively. The heart doses obtained from the IMRT and VMAT plans are given in detail in Table 4.

\section{Medulla Spinalis}

The median medulla spinalis maximum dose was found the lowest in VMAT (41.54 Gy) planning and the highest in IMRT (43.43 Gy) planning. No statistically significant difference was observed between the two techniques in terms of cord $\mathrm{D}_{\max }(\mathrm{p}=$ 0.074).

\section{Monitor Unit}

Table 5 gives the monitor unit (MU) values for the different treatment plans. In the comparison of the two different planning techniques in terms of MU, it was found that the IMRT technique had statistically significantly higher MU value compared to VMAT $(\mathrm{p}=0.005)$.

\begin{tabular}{|c|c|c|c|c|c|c|}
\hline & \multicolumn{6}{|c|}{ Heart } \\
\hline & \multicolumn{2}{|l|}{$\mathbf{V}_{30}$} & \multicolumn{2}{|l|}{$\mathbf{V}_{40}$} & \multicolumn{2}{|c|}{ MHD } \\
\hline & IMRT & VMAT & IMRT & VMAT & IMRT & VMAT \\
\hline Median & 43.00 & 44.03 & 21.35 & 18.95 & 29.31 & 28.81 \\
\hline (Min-Max) & (26.60- 75.60) & (19.60-51.63) & $(10.18-30.80)$ & (6.40-23.30) & $(21.78-35.61)$ & (19.60-30.02) \\
\hline Mean & 46.00 & 38.81 & 21.23 & 15.35 & 29.13 & 27.60 \\
\hline $\mathrm{SD}^{*}$ & 13.15 & 8.55 & 7.19 & 5.17 & 3.80 & 3.20 \\
\hline$p$ & \multicolumn{2}{|l|}{0.114} & \multicolumn{2}{|l|}{0.005} & \multicolumn{2}{|c|}{0.114} \\
\hline
\end{tabular}


Table 5. Monitor unit values of the techniques

\begin{tabular}{lll} 
Technique & Mean $\mathbf{M U}$ & $\mathbf{p}$ \\
\hline IMRT & $1341 \pm 637$ & 0.005 \\
VMAT & $516 \pm 110$ &
\end{tabular}

\section{DISCUSSION}

Because of the midline location of the target and the presence of several critical organs such as heart, lung, medulla spinalis with different densities around it, the planning of mid-thoracic esophageal tumor radiotherapy plans is very difficult. In parallel with current developments in radiotherapy, treatments have shifted from 3D-CRT to IMRT and VMAT planning. Although advanced radiotherapy techniques outperform conformal techniques in terms of PTV conformity, each technique has different advantages over other in terms of normal tissue protection. In studies conducted, IMRT technique provides more homogeneous dose in target and lower dose in lungs, however, it leads to treatment practices with a higher monitor unit, which is important for secondary cancers. ${ }^{13}$ In the VMAT technique, dosimetric results similar to the IMRT technique can be obtained using one or more arcs. ${ }^{14}$ Many studies have been conducted whether IMRT or VMAT technique is more beneficial for esophagus radiotherapy and comparing several techniques is the topic of discussion.

In radiotherapy planning, the prescribed dose is intended to be given to the target volume with high homogeneity and high conformity. In our study, similar results were found in terms of homogeneity and conformity between IMRT and VMAT planning and no statistical difference was found between two techniques. In the study by Vivekanandan et al., plans made with 4 different techniques including 3D-CRT, 4-field IMRT, single arc and double arc were compared in 10 patients with esophageal cancer. ${ }^{14}$ Similar to our study, the IMRT and double arc VMAT plans did not differ statistically in terms of homogeneity $(\mathrm{p}<0.05)$, but a more homogenous dose distribution was achieved with VMAT. In terms of conformity, the VMAT technique $(\mathrm{CI}=1.01)$ was found to be significantly bet- ter than the IMRT technique $(\mathrm{CI}=1.13)(\mathrm{p}=0.02)$.

While achieving the best dose distribution in the target volumes is the aim of radiotherapy practices, plans should also be carefully examined in terms of both early and late side effects in normal tissues at risk. In esophageal cancer radiotherapy planning, predictors for toxicity in the lungs, which are known to be one of the most radiation sensitive tissues, are related to lung dose distributions. There are studies in the literature reporting that mean lung dose and lung $\mathrm{V}_{5}, \mathrm{~V}_{10}$ and $\mathrm{V}_{20}$ values correlate significantly with the risk of radiation pneumonia. ${ }^{15-19}$ In the study that Schallenkamp et al. conducted on 99 patients, it is reported that a high volume receiving a low dose in the lungs is more determining of radiation pneumonia than lung $\mathrm{V}_{20}$ and $\mathrm{V}_{30}$ values. ${ }^{16}$ Although a single dose-volume histogram (DVH) value is not the main determinant for lung pneumonia, a high volume receiving a low dose is a poor indication.

In our study, the lung $\mathrm{V}_{5}$ parameter was higher in the VMAT plan (74\%) compared to the IMRT technique due to the use of 2 full arcs. However, in the IMRT technique where fixed angles are used, the lung $\mathrm{V}_{5}$ value is $63 \%$. In a study by Lin et al., IMRT and VMAT techniques were compared in 20 esophageal cancer patients with different esophageal tumor locations. ${ }^{9}$ As a result of the study, a lower $\mathrm{V}_{5}$ and mean lung dose was achieved in the upper thoracic region with the IMRT technique, while no significant difference in PTV conformity was observed $(\mathrm{p}=0.357)$. Similarly, a lower $\mathrm{V}_{5}$ $(41.85 \%$ and $47.56 \%)$ and mean lung dose (941 cGy and 987 cGy) were achieved in the mid-thoracic region with IMRT plans compared to VMAT planning, while an increase was observed in the $\mathrm{V}_{20}(17.80 \%$ and $16.01 \%)$, medulla spinalis maximum dose (4200 cGy and $4140 \mathrm{cGy}$ ), and mean heart dose (1731 cGy and $1517 \mathrm{cGy}$ ). However, the IMRT technique was found to be superior to the VMAT technique in terms of PTV in this region. In the lower thoracic region, no significant difference was observed between the two techniques in terms of PTV, although lung, heart, and medulla spinalis results were the same as those obtained in the middle thoracic region. These results are consistent with the results of our study evaluating 
techniques in mid-thoracic esophageal radiotherapy. In terms of the $\mathrm{V}_{10}$ parameter, a statistical difference was observed between the IMRT technique and the VMAT technique in our study $(\mathrm{p}=0.038)$ and while the median $\mathrm{V}_{10}$ value obtained in IMRT planning was 41.95 , this value was 44.13 in VMAT planning.

In our study, there was no statistically significant difference $(p=0.092)$ between the two planning techniques in terms of the lung mean $\mathrm{V}_{20}$ value, but while the $\mathrm{V}_{20}$ value was 20\% in VMAT planning, it was $23 \%$ in IMRT planning. However, in the study by Vivekanandan et al., the target conformity was better in the VMAT technique than IMRT plans in 10 esophagus patients. ${ }^{14}$ Lung $\mathrm{V}_{20}(15.46 \%$ and $13.81 \%)$ and $\mathrm{V}_{30}(6.82 \%$ and $5.59 \%)$ values were observed to be lower in VMAT planning compared to IMRT. In the study by Lin et al., the lung $\mathrm{V}_{20}$ values $(17.80 \%$ and $16.01 \%)$ was found to be lower in VMAT planning compared to the IMRT technique in mid-thoracic esophageal tumors.

In our study, the median mean lung dose was 12.05 Gy in the IMRT technique and $11.77 \mathrm{~Gy}$ in the VMAT technique and there was no statistical difference between the two techniques $(p=0.575)$. In the study by Lin et al., the MLD was found to be significantly lower in IMRT planning compared to VMAT planning $(\mathrm{p}=0.001){ }^{9}$ On the contrary, in the study by Zhang et al., it was found to be higher with IMRT planning compared to double arc VMAT planning $(\mathrm{p}=0.013){ }^{20}$ We think that these different results in the literature are due to location of the selected tumour, used angles, single or double arc usage and differences of optimization.

In terms of heart $\mathrm{V}_{30}$ values, the VMAT technique and the IMRT technique showed similar results statistically ( $p=0.114)$ in our study, but with the $\mathrm{V}_{40}$ median values, the VMAT technique (18.95 Gy) yielded significantly lower values than the IMRT technique (21.35 Gy). In addition, in the study by Kataria et al. comparing the IMRT and VMAT techniques in esophageal cancer, no significant difference was observed in terms of the heart V30 and $\mathrm{V}_{40}$ parameters $(\mathrm{p}=0.352$ and 0.188$)$, but the VMAT technique was found to be $1.6 \%$ and $0.85 \%$ lower than the IMRT technique, respectively. ${ }^{21}$ In the study by Lin et al., the heart $\mathrm{V}_{40}$ value was about 2 Gy lower than IMRT planning in VMAT plans. A similar finding was observed in the MHD. Likewise, the result of the study by Vivekanandan et al. showing that the double arc VMAT technique yielded a better result in terms of MHD compared to conformal and IMRT planning supports our study (35.95 Gy and 32.58 Gy). ${ }^{14}$ Therefore, it can be said that the VMAT technique has the advantage of protecting the heart in the treatment of the esophagus.

Although there was no statistically significant difference between the IMRT and VMAT techniques in terms of the medulla spinalis $\mathrm{D}_{\text {max }}$ parameter, lower dose values were obtained with the VMAT technique. However, in the study by Lin et al., a significant difference was observed between VMAT and IMRT $(\mathrm{p}=0.026)$ in the mid-thoracic region and a higher Dmax value (4200 cGy and 4140 cGy) was reported with IMRT planning compared to VMAT. ${ }^{9}$ In addition to this, the study by Zhang et al. showed that the double-arc VMAT plans gave a similar $\mathrm{D}_{\max }$ value compared to IMRT plans $(\mathrm{p}=0.976){ }^{20}$

In our study, the monitor units yielded about $61 \%$ lower values in VMAT planning $(516 \pm 110)$ compared to IMRT planning (1341 \pm 637$)$. The high level of monitor unit obtained with IMRT planning increases the duration of treatment and also adversely affects the possibility of secondary cancer. Thus, with VMAT planning, treatment time is reduced with much lower monitor units compared to IMRT planning, and dosimetric uncertainties in planning are also reduced.

We have some limitations in this study. We compared two different techniques for only dosimetric parameters. Although, we know that volumes of PTV and normal tissues at risk and their ratio may effect $\mathrm{V}_{\mathrm{x}}$ parameters in dosimetry, PTV and normal tissue volumes were not evaluated in this study. The ratio between PTV and normal tissue volumes has significant impact on $\mathrm{V}_{\mathrm{x}}$ values as the ratio increases the expected $\mathrm{V}_{5}, \mathrm{~V}_{10}, \mathrm{~V}_{20}$, mean doses would increase.

Although, we know that different algorithms and priority values are used for optimization of IMRT or VMAT regarding to clinical experiences, normal tissues tolerance protocols and facilities of treat- 
ment planning system. The effect of dosimetric optimization algorithm was not evaluated in this study. It should be discussed in elsewhere.

In conclusion, the plans made with the IMRT technique in our study showed similar results in terms of homogeneity and conformity, but better PTV, $\mathrm{D}_{95}$, and $\mathrm{D}_{98}$ values were obtained with the IMRT technique. In normal tissues, due to the volumetric arc treatment, a higher lung $\mathrm{V}_{5}$ value was obtained with the VMAT technique and a higher heart $\mathrm{V}_{30}$ value was obtained with the IMRT technique. In choosing a treatment plan for patients with midthoracic esophageal location, it is extremely important to evaluate the normal tissue doses as well as the tumor target volume doses. The normal tissue doses of different planning techniques should be assessed taking into account other factors such as age of the patient, clinical performance status, accompanying cardiac or pulmonary diseases, and smoking history.

\section{REFERENCES}

1. Desantis CE, Lin CC, Mariotto AB, et al. Cancer Treatment and Survivorship Statistics, CA Cancer J Clin 64: 252-271, 2014.

2. Tachimori Y. Pattern of lymph node metastases of esophageal squamous cell carcinoma based on the anatomical lymphatic drainage system, J Thorac Dis 9 (Suppl 8): 724-730, 2017.

3. Sohda W, Kuwano H. Current status and future prospects for esophageal cancer treatment, Ann Thorac Cardiovasc Surg 23: 1-11, 2017.

4. Badwe RA, Sharma V, Bhansali MS, et al. The quality of swallowing for patients with operable esophageal carcinoma: a randomized trial comparing surgery with radiotherapy. Cancer 85: 763-768, 1999.

5. Rice TW, Rusch WW, Apperson-Hansen C, et al. Worldwide esophageal cancer collaboration. Dis Esophagus 22: 1-8, 2009.

6. Cooper JS, Guo MD, Herskovic A, et al. Chemoradiotherapy of Locally Advanced Esophageal Cancer: Long-term Followup of a Prospective Randomized Trial (RTOG 85-01). JAMA 281: 1623-1627, 1999.

7. Tepper J, Krasna MJ, Niedzwiecki D, et al. Phase III trial of trimodality therapy with cisplatin, fluorouracil, radiotherapy, and surgery compared with surgery alone for esophageal cancer. CALGB 9781. J Clin Oncol 26: 1086-1092, 2008.
8. Stahl M, Stuschke M, Lehmann N, et al. Chemoradiation with and without surgery in patients with locally advanced squamous cell carcinoma of the esophagus. J Clin Oncol 23: 2310-2317, 2005.

9. Lin JC, Tsai JT, Chang CC, et al. Comparing treatment plan in all locations of esophageal cancer. Medicine (Baltimore) 94: e750, 2015.

10. International Commission of Radiation Units and Measurements, (ICRU) Report 83. Prescribing, recording, and reporting intensity-modulated photon-beam therapy (IMRT) 2010.

11. Wang $X C$, Zhang $X D$, Dong $L$, et al. Effectiveness of noncoplanar IMRT planning using a parallelized multiresolution beam angle optimization method for paranasal sinus carcinoma. Int J Radiat Oncol Biol Phys 63: 594-601, 2005.

12. Paddick I. A simple scoring ratio to index the conformity of radiosurgical treatment plans. J Neurosurg 93: 219-222, 2000.

13. Nutting CM, Bedford JL, Cosgrove VP, et al. A comparison of conformal and intensity- modulated techniques for oesophageal radiotherapy. Radiother Oncol 61: 157-163, 2001.

14. Vivekanandan N, Sriram P, Kumar S, et al. Volumetric modulated arc radiotherapy for esophageal cancer. Med Dosim 37: 108-113, 2012.

15. Tucker L, Liu H, Wang S, et al. Dose-volume modeling of the risk of post operative pulmonary complications among esophageal cancer patients treated with concurrent chemoradiotherapy followed by surgery. Int J Radiat Oncol Biol Phys 66: 754-761, 2006.

16. Schallenkamp JM, Miller RC, Brinkmann DH, et al. Incidence of radiation pneumonitis after thoracic irradiation: Dose-volume correlates. Int J Radiat Oncol Biol Phys 67: 410-416, 2007.

17. Graham MV, Purdy JA, Emami B, et al. Clinical dose-volume histogram analysis for pneumonitis after 3D treatment for non-small cell lung cancer (NSCLC). Int J Radiat Oncol Biol Phys 45: 323-329, 1999.

18. Tsujino K, Hirota S, Endo M, et al. Predictive value of dosevolume histogram parameters for predicting radiation pneumonitis after concurrent chemoradiation for lung cancer. Int $\mathrm{J}$ Radiat Oncol Biol Phys 55: 110-115, 2003.

19. Yorke ED, Jackson A, Rosenzweig KE, et al. Correlation of dosimetric factors and radiation pneumonitis for non-small cell lung cancer patients in a recently completed dose escalation study. Int J Radiat Oncol Biol Phys 63: 672-682, 2005.

20. Zhang WZ, Zhai TT, Lu JY, et al. Volumetric modulated arc therapy vs. C-IMRT for the treatment of upper thoracic esophageal cancer. PloS One 10(3): e0121385, 2015.

21. Kataria T, Govardhan HB, Gupta D, et al. Dosimetric comparison between Volumetric Modulated Arc Therapy (VMAT) vs Intensity Modulated Radiation Therapy (IMRT) for radiotherapy of mid esophageal carcinoma. J Cancer Res Ther 10: 871-877, 2014. 
International Journal of Hematology and Oncology

\section{Correspondence:}

Fiz. Uzm. Adem Emre KARAOGUZ

Dokuzeylül Üniversitesi Tip Fakültesi

Radyasyon Onkolojisi Anabilim Dali,

Medikal Fizik Bilim Dali

Tibbi Fizik Bilim Dali

Mithatpasa Caddesi, No: 1606

35340 Balçova

IZMIR / TURKEY

Tel: (+90-232) 4122222

Fax: (+90-232) 4129797

email: emre.karaoguz@gmail.com 